\title{
CRIMINAL VIOLENCE AND ALCOHOL BEVERAGE CONTROL: EVIDENCE FROM AN INTERNATIONAL STUDY
}

\author{
Sara Markowitz \\ Working Paper 7481 \\ http://www.nber.org/papers/w7481 \\ NATIONAL BUREAU OF ECONOMIC RESEARCH \\ 1050 Massachusetts Avenue \\ Cambridge, MA 02138 \\ January 2000
}

The views expressed herein are those of the author and not necessarily those of the National Bureau of Economic Research.

(C) 2000 by Sara Markowitz. All rights reserved. Short sections of text, not to exceed two paragraphs, may be quoted without explicit permission provided that full credit, including $\mathbb{C}$ notice, is given to the source. 
Criminal Violence and Alcohol Beverage Control:

Evidence from an International Study

Sara Markowitz

NBER Working Paper No. 7481

January 2000

JEL No. I10

\section{ABSTRACT}

The purpose of this paper is to examine the relationship between the price of alcoholic beverages and the incidence of criminal violence in different countries around the world. The positive association between alcoholic beverage consumption and violence is well documented, as is the negative relationship between the quantity of alcohol consumed and its price. These two relationships together form the principal hypothesis of whether increases in alcoholic beverage prices will directly decrease the incidence of criminal violence. The data come from the 1989 and 1992 International Victimization Surveys. The sample used in this paper is comprised of almost 50,000 respondents in 16 different countries. The respondents were asked if they had been victims of three types of violent crimes in the past year: robbery, assault, and sexual assault (female respondents only). A reduced form model is estimated where the probability of being a victim of violent crime is determined by the price of alcohol, variables describing the area the person lives in, and other socio-economic characteristics of the respondent. Country fixed effects are also employed in some models. Results indicate that higher alcoholic beverage prices lead to lower incidences of all three types of violent crime in models where country fixed effects are not included. Results from models which include country fixed effects are not reliable.

Sara Markowitz

New Jersey Institute of Technology

365 Fifth Avenue, 5th Floor

New York, NY 10016

and NBER

markowitz@admin.njit.edu 


\section{INTRODUCTION}

Violent crime is a serious social problem faced by almost all nations around the world. Studies from many different countries show that there is a well established link between alcohol consumption and violence (see Miczek et al., 1993, for a complete review of the literature).

When studying criminal violence, there are two aspects of the drinking/violence relationship that must be addressed. The first is the relationship between alcohol consumption by the perpetrator and his or her propensity towards violence, while the second focuses on the alcohol consumption of the potential victim, which may put him or her at a higher risk for victimization.

Focusing first on the perpetrator's alcohol consumption, many studies show a direct link between alcohol use and criminal violence. For example, the Bureau of Justice Statistics (1988) reports that in the United States, about 60 percent of all persons convicted of assault had been drinking just prior to the crime. By contrast, about 40 percent of burglars and 30 percent of drug offenders used alcohol just prior to the crimes that they had committed. Other studies of crime outside the United States find similar results. Using samples of violent and non-violent Scottish prisoners, Myers $(1982,1986)$ finds that violent offenders were more likely to have consumed alcohol at the time of the offence than non-violent offenders. Roslund and Larson (1979) find that 68 percent of violent offenders in Sweden were intoxicated when committing crimes as compared to 38 percent of non-violent offenders. It is important to note that these studies do not establish causality from drinking to violence, rather they highlight an association between the two behaviors.

Some studies have revealed that it is not only the criminals who consume alcohol prior to committing crimes, but the victim's consumption behavior may inadvertently put him or her at 
risk. According to the "lifestyle" theory of victimization, "persons who drink extensively or go 'cruising' for social activity, especially at night, are at higher risk for assault because such behavior often occurs at bars, parties, and other places where victimization risk is heightened." (Sampson and Lauritsen, 1994, p. 32). Drinking may also lower guardianship potential which can lead to increased victimization risk for assault and other personal crimes such as rape and robbery. In fact, many studies have shown a high prevalence of alcohol in both the offender and the victims of aggression. For example, Johnson et al. (1978) examine a sample of rapes in Winnipeg, Canada from 1966-1975. They find that in 72 percent of the cases, alcohol was used by the victim and/or offender, with alcohol being used by both the victim and the offender in 39 percent of the cases. Alcohol was used by the victim only (and not by the offender) in 9 percent of the cases and by the offender only in 24 percent of the cases. In studies on homicides, Virkkunen (1974) shows that alcohol was generally present in both victims and murderers in Helsinki from 1963-1968, and Lindqvist (1986) finds that in Sweden from 1970-1980, 47 percent of both the murderers and victims were intoxicated during the attack.

In addition to the well established link between alcohol consumption and violence, alcohol consumption has been shown to be negatively related to the price of alcoholic beverages. (See for example Kenkel, 1993, Leung and Phelps, 1993, Manning et al., 1995, and Grossman, et al., 1998.) Given these two relationships, the purpose of this paper is to examine the direct relationship between the price of alcohol and the incidence of criminal violence. This study focuses on prices rather than consumption as a potential tool to reduce violence since the easiest way for governments to achieve reductions in consumption is to increase the price through tax increases.

The data come from the 1989 and 1992 International Victimization Surveys. The 
respondents were asked if they had been victims of three types of violent crime in the past year: robbery, assault, and sexual assault (female respondents only). This is the first study to relate alcoholic beverage prices to criminal violence in an international framework. One advantage of using a cross-country analysis is that there are much larger variations in prices and crime rates than in a within country analysis. Results of this study show that higher alcoholic beverage prices lead to lower incidences of all three types of violent crime in models where country fixed effects are not included. Results from models which include country fixed effects are not reliable.

\section{LITERATURE REVIEW}

There have been very few studies relating the determinates of alcohol consumption to incidence of criminal violence. Cook and Moore (1993) and Chaloupka and Saffer (1992) both examine the effects of alcohol prices on a time series of aggregate state crime rates in the United States. In particular, both sets of authors look at rates of murder, rape, assault, and robbery. Cook and Moore model criminal offenses as a function of alcohol consumption and the socioeconomic and demographic characteristics of a state's population. Chaloupka and Saffer expand the model to include drug consumption and law enforcement as variables affecting crime rates. Alcohol consumption (as well as drug consumption in Chaloupka and Saffer) is treated as endogenous and is determined by price, availability, sentiment towards drinking, and laws designed to curtail consumption. Both sets of authors choose to address the endogeneity by using a reduced form model where a specific crime rate is a function of the state excise tax on beer and other demographic variables. Chaloupka and Saffer also include variables that may affect the availability of alcohol such as the minimum legal drinking age and the percentage of a 
state's population living in dry counties. Results of both studies indicate that increasing the tax on beer reduces most types of violent crimes (with the exception of assault) while the effects of the availability and control measures used by Chaloupka and Saffer are mixed.

Other evidence on the effects of alcohol consumption and availability on crime rates comes from Scandinavian studies. One study by Lenke (1975) shows that there is a high statistical correlation between rates of violent crime and per capita alcohol consumption in several Scandinavian countries during the period 1960-1973. In addition, Lenke (1975) and Takala (1973) look at changes in alcohol prices, incidence of strikes by employees of liquor stores, and introduction of new sales points (i.e. selling beer in grocery stores) to explain changes in violent crime rates. Both studies show that violent crimes decrease when alcohol is less available.

Finally, studies of the effects of higher alcohol prices on other types of violence include studies on child abuse (Markowitz and Grossman, 1998a and forthcoming), spousal abuse (Markowitz, 1999) and violence on college campuses (Grossman and Markowitz, 1999). These studies all show that increasing the price of alcohol is an effective way to reduce the incidence of violence.

This current project expands on the existing literature by focusing on criminal victimization, as reported by the victims, in a cross-country framework. The studies cited above by Cook and Moore and Chaloupka and Saffer use U.S. state-level data from the Uniform Crime Reports. One advantage of using individual-level data over aggregate-level data is that the characteristics of the victim can be controlled for. Aggregate-level data presents another problem in that often the sources of data, such as the Uniform Crime Reports, only include crimes that had been reported to the police. In the United States, for example, the 1994 National 
Crime Victimization Survey estimates that less than half (41.6 percent) of violent crimes were reported to police. The use of aggregate data may cause the price coefficient in the reduced form equation to be biased because of measurement error. If this measurement error is random, the only effect would be to raise the standard errors of the coefficients on all the independent variables. However, if crime is systematically underreported and correlated with the price of alcohol then the coefficient on price would be biased. Such a situation might occur if people in areas with low alcoholic beverage prices consume more, live in areas with higher crime rates, and are less likely to report crimes to the police, perhaps because of perceived police inaction or lack of trust in the police.

\section{ANALYTICAL FRAMEWORK}

As mentioned above, the many studies on crime and drinking do not establish a direction of causality from alcohol consumption to violence. In fact, there is no general agreement in the existing literature on the direction of the causality. One prominent theory is that alcohol use does promote violence through a pharmacological mechanism that alters behavior (Pernanen, 1981 and Fagan, 1993). This theory states that alcohol use causes violence. A competing theory proposes that violence may cause alcohol consumption in that people who plan on being violent may drink in order to give themselves courage or an excuse for the behavior (Fagan, 1990 and Cordilia, 1985). ${ }^{1}$ Finally, a third theory states that alcohol and violence are both outcomes of an unobserved third factor, for example, a risk-taking personality (Fagan, 1990). As discussed below, these competing theories are not problematic for the analytical framework.

The analytical framework is derived from the economic models of crime developed by Becker (1968), Chaloupka and Saffer (1992) and Cook and Moore (1993). Criminal violence is 
determined by both the actions of the perpetrator and the victim. Taking into account the drinking habits and personal characteristics of both the potential criminal and victim gives the following equation for violence:

1) $\quad V_{i}=v\left(A_{i}, A_{j}, E, Y_{i}, Y_{j}, U_{i}, U_{j}\right)$.

Equation 1, termed the structural violence equation, shows that the probability of being a victim of a violent crime $\left(V_{i}\right)$ is a function of the alcohol consumption of the individual, $A_{i}$, who is the potential victim, the alcohol consumption of other individuals $\left(A_{j}\right)$ who can be strangers or acquaintances and are potential perpetrators, law enforcement variables (E), and other observed factors of individuals $\left(\mathrm{Y}_{\mathrm{i}}, \mathrm{Y}_{\mathrm{j}}\right)$ which affect the propensity towards crime or victimization such as age, gender, income, and employment status. Unobserved individual-level factors $\left(\mathrm{U}_{\mathrm{i}}, \mathrm{U}_{\mathrm{j}}\right)$ which influence the probability of violent crime are also included.

Alcohol consumption by either party can be expressed as a demand function: 2) $\mathrm{A}=\mathrm{a}\left(\mathrm{P}_{\mathrm{A}}, \mathrm{Y}, \mathrm{U}\right)$, where $\mathrm{P}_{\mathrm{A}}$ is the full price of alcohol, and $\mathrm{Y}$ and $\mathrm{U}$ are individual characteristics that may determine consumption. These sets of characteristics may be the same ones that determine violence. The full price of alcohol reflects both the monetary price of alcohol and other costs of obtaining the substance, such as time and travel costs.

Substituting equation 2 into equation 1 gives a reduced form estimate for violence:

$$
\mathrm{V}_{\mathrm{i}}=\mathrm{v}\left(\mathrm{P}_{\mathrm{A}}, \mathrm{E}, \mathrm{Y}_{\mathrm{i}}, \mathrm{Y}_{\mathrm{j}}, \mathrm{U}_{\mathrm{i}}, \mathrm{U}_{\mathrm{j}}\right) \text {. }
$$

Given that the crimes examined in this study are crimes of personal contact, the victim and the criminal will be located in close proximity and thus face the same price of alcohol. Equation 3 cannot be fully estimated empirically because data on crimes typically have characteristics on either the perpetrator or the victim, but not both. In light of this, a modified version of equation 
3 serves as the basis for estimation in this paper where incidents of victimization are observed:

4) $\quad V_{i}=v\left(P_{A}, Y_{i}, e\right)$

where e is an error term that contains $\mathrm{E}, \mathrm{Y}_{\mathrm{j}}, \mathrm{U}_{\mathrm{j}}$, and $\mathrm{U}_{\mathrm{i} \cdot}{ }^{2}$ A negative sign on the price coefficient indicates that an increase in the price of alcohol will lead to a reduction in violence. This reduction in violence is a result of decreased consumption by both the potential victim and the perpetrator. ${ }^{3}$ Using country specific fixed effects will help control for some of the unmeasured characteristics in the error term. However, omitting individual characteristics of either the perpetrator or the victim should not be problematic so long as these variables are uncorrelated with the price of alcohol, the variable of interest in this paper.

In estimating equation 4 , the direction of causality between alcohol and violence is not a problem because consumption is substituted out of the equation. If alcohol causes violence then the coefficient on the price of alcohol will be negatively related to violence. If violence causes consumption, then changing consumption through prices would have no measurable effect on violence and the coefficient on the price in the reduced form would reflect this. If, however, there is an unmeasured third factor that determines both consumption and violence, then so long as the price is uncorrelated with this third factor, estimating equation 3 will produce unbiased estimates of the effect of price on violence. (See Cook and Moore, 1993 for a further discussion of these issues.)

\section{$\underline{\text { IV. DATA }}$}

The data come from the 1989 and 1992 cross sections of the International Victimization Survey conducted by the Dutch Ministry of Justice. These surveys are random samples of individuals ages 16 and older, and are designed to measure the experience of crime and crimerelated issues in a variety of countries around the world. The 1989 survey consists of responses 
from approximately 2000 individuals in each of 14 countries, while the 1992 survey has respondents from 18 countries. Not all countries in the surveys are used because of the lack of corresponding alcohol control variables, and the same country is not necessarily included in both years. There are eight countries that appear in both survey years: Australia, Belgium, Canada, Finland, the Netherlands, Spain, the United Kingdom, and the United States. The 1989 survey also includes France, Germany, Japan, Norway, and Switzerland, while the 1992 survey includes Italy, New Zealand and Sweden.

\section{$\underline{\text { A. Dependent Variables }}$}

Three questions in the International Victimization Surveys focus on violent crimes. First, respondents are asked about robbery or attempted robbery in the past year. Specifically, the question asks if anyone has taken something from the respondent by using force or threatening them, or did anyone try to do so. About 0.8 percent of the sample were victims of robbery in 1988 and 1.1 percent were victims in 1991. The second question asks about assault. In other words, had the respondent been personally attacked or threatened by someone in a way that really frightened them, either at home, or elsewhere, such as in a pub, the street, at school, on public transportation, in cinemas, on the beach, or at one's workplace. In 1988, 2.9 percent of respondents were victims of assault while 3.3 percent were victims in 1991 . The third dependent variable focuses on sexual assault against women only. The question on sexual assault reads, "People sometimes grab, touch or assault others for sexual reasons in a really offensive way. This can happen inside one's house or elsewhere, for instance, in a pub, the street, at school, on public transportation, in cinemas, on the beach, or at one's workplace. Has anyone done this to you?" In 1988, 2.6 percent of women were victims of sexual assault and in 1991, 2.3 percent of 
women were victims.

Table 1 shows rates of violence by year and country. Notice that Japan has no reported cases of robbery in 1988 . Finding no robberies in a sample of 2,411 Japanese individuals is quite likely because Japan has very low crime rates in general. Dolan and Worden (1994) find that in 1989, Japan experienced 1.3 robberies per 100,000 population, as compared with 48.6 for West Germany, 65.8 for Britain, and 233.0 for the United States. These data come from the United Nations Survey of Crime Trends and Operations of Criminal Justice Systems, which gives rates of crimes that are reported to the police. These robbery figures are much lower than the rates presented in Table 1 because the International Victimization Surveys include attempted crimes and crimes which are not necessarily reported to authorities. In fact, in the International Victimization Surveys, less than half (43 percent) of the respondents who admitted to having been robbed reported the robbery to the police.

Even though the levels of crime vary widely between the U.N. survey and the data presented here, the ranking of countries by crime rates is very similar in both surveys. For example, Spain, the U.S., and Canada rank first, second, and third for the most robberies per capita in 1988 in both the U.N. survey and the International Victimization Survey, whereas Finland ranks near the bottom and Japan is last. Similar ranks hold for robbery in the 1991 surveys. Canada and the U.S. also consistently rank at the top of the list for assault while Italy and Japan rank at the bottom. The rankings for sexual assault vary widely between the surveys primarily because of inconsistent reporting methodologies across countries.

\section{B. Independent Variables}

Two different measures are used to represent the price of alcohol. The first is the price of 
one ounce of pure alcohol expressed in real $(1992=1)$ U.S. dollars and the second is the tax on one ounce of pure alcohol expressed in real U.S. dollars. Including the tax on alcohol, besides providing an alternative measure of price, will provide a direct estimate of the ability of governments to affect violence rates through tax increases. Actual prices and taxes on alcohol by country are not available but household expenditures on alcohol, total tax revenue, and consumption data are available. The price and the tax on alcohol for each country are constructed by the following formulas:

5) $\quad \mathrm{P}=\mathrm{E} /\left(\mathrm{C}^{*} \mathrm{PPP} * \mathrm{D}\right)$, and

6) $\mathrm{T}=\mathrm{R} /(\mathrm{C} * \mathrm{PPP} * \mathrm{D})$,

where $\mathrm{E}$ is per capita expenditures on all alcoholic beverages expressed in the national currency, $\mathrm{R}$ is per capita tax revenue from alcohol expressed in the national currency, $\mathrm{C}$ is the sum of per capita consumption of the pure alcohol from beer, wine and liquor in a country, PPP is purchasing power parity (national currency per U.S. dollar), and D is the GDP deflator for the United States. ${ }^{4}$ This is the same procedure used by Saffer (1991) to calculate the price of alcohol in OECD countries. Total tax revenue $(\mathrm{R})$ is reported as the sum of excise taxes, duties on monopolies, specific customs duties and special taxes on catering establishments. The consumption of alcohol includes sake for Japan and cider for England and Switzerland. Expenditures on alcohol, tax revenues from alcoholic beverages, the GDP deflator and the purchasing power parity all come from the OECD Health Data 1997 data base. Consumption data come from the Brewers Association of Canada's, Alcoholic Beverage Taxation and Control Policies (1997).

Table 1 shows there is much variation in the price and tax on alcohol among countries. However, the constructed prices of alcohol can differ among countries because of variations in 
consumption shares, rather than from actual price differences. If, for example, two countries face the same price for liquor, but the share of total consumption for liquor is higher in one country, then the constructed price will differ because of the consumption differences. In order to control for this problem, the percentage of total consumption from wine and liquor for each country are included in all models. Including the percentage of total consumption also allows the models to control for countries which are predominately beer or wine drinking, and thus control for some of the unobserved sentiment towards consumption. ${ }^{5}$

Three other alcohol control variables are included in the models in order to account for country-specific factors that may affect the availability or full price of alcohol. All three variables come from Alcoholic Beverage Taxation and Control Policies (Brewers Association of Canada, 1997). The first variable is the legal blood alcohol level indicative of impaired or drunk driving. Higher legal blood alcohol levels may result in more consumption (and more violence) because higher blood alcohol levels make it harder to penalize drivers for driving while intoxicated. That is, the expected costs of drunk driving are lower with higher blood alcohol levels. Higher blood alcohol levels may also be indicative of more tolerance towards drinking in a nation. Legal blood alcohol levels range from practically zero (Japan has no tolerance for drunk driving) to 0.10 . The majority of countries have levels of 0.05 or 0.08 . The second variable is a dichotomous indicator for alcohol advertising. This variable equals 1 if a country bans beer, wine and liquor advertising on television or radio. ${ }^{6}$ Five of the sixteen countries in the surveys have implemented this ban. Advertising of alcohol can either affect total consumption or brand choice decisions, although Saffer (1991) shows that quantity consumed is lower in countries which ban broadcast advertising of alcoholic beverages. Finally, the minimum legal drinking age for purchase of beer or wine is included. In some countries, the minimum legal 
drinking age differs for consumption on-premise (in a bar or restaurant) or off-premise. In these cases, the age used is an average of the minimum legal ages for on- and off-premise. Minimum legal drinking ages generally range from ages 16 to 21, but Belgium had no minimum age for off-premise consumption.

Per capita disposable income in real U.S. dollars for each country is included in all models because this variable may control for some substitution in consumption of different quality beer, liquors and wines. That is, as people get richer, they may substitute high quality alcohol for the cheaper brands. Such a substitution would result in higher total consumer expenditures on alcohol and thus, a higher calculated price. The calculated tax is less subject to this problem since most countries collect both excise taxes and ad valorem taxes. Per capita disposable income comes from the OECD Health Data 1997 data base.

Other variables which account for characteristics of the respondent and the locational characteristics of the respondent are also included. Specifically, all models include the respondent's gender, age, a dichotomous indicator for whether the respondent's income is higher than the country's median income, and employment status (part-time worker, unemployed, student, or other occupation which includes individuals who are retired, in the armed services or are homemakers). The number of days per year the respondent goes out in the evening for recreational purposes (to a pub, restaurant, cinema or to see friends) is also included. This variable is important in that people who are out late at night may be more likely to be victims of crime. The National Research Council, 1993, notes that "nighttime activity outside the home" is the social behavior most highly associated with violent victimization in the United States. This same source cites similar results in Canadian and British surveys. Finally, a dummy for 1991 and the size of the town that the respondent lives in are also included in all models. Any missing 
values on the individual level variables are replaced with year and country specific means. An alternative strategy would be to delete the incomplete observations. This strategy gives results very similar to those presented here.

\section{ESTIMATION}

The probability of being a victim of violent crime is estimated using probit techniques. Tables 2, 3, and 4 show the results for robbery, assault, and sexual assault against females, respectively. Each table contains four models. Columns 1 and 2 use the calculated price of alcohol while columns 3 and 4 include the tax on alcohol. Columns 1 and 3 are otherwise identical in that each includes a price of alcohol, the other three regulatory variables (the legal blood alcohol level, the indicator for the ban of alcohol advertising on radio and television, and the minimum legal drinking age), and the individual characteristics. The models in columns 2 and 4 include country fixed effects, and thus are limited to the set of countries that are included in both years of the survey. ${ }^{7,8}$ The advertising ban and minimum legal drinking age cannot be included in the models with the country dummies because the values of variables do not change over the two years of the survey.

The fixed effects models are important because these models can capture the unobserved effects of culture on crime and drinking in each country. Japan, for instance, has a very low crime rate because of emphasis on family honor. In addition, reliable criminal justice data such as expenditures on law enforcement are not available for many countries. Omitting the fixed effects can result in biases in the included variables if they are correlated with the country level unobservables. However, in order to include the country dummies, it is necessary to limit the sample to only the eight countries which appear in both years of the survey. Hence, models are presented both with the larger sample of all countries, and with the smaller sample that includes 
the country dummies.

Each table lists the probit coefficients first, the t-statistic on the coefficients in parentheses, and the marginal effects of the coefficients in bold italics. The marginal effects shown for the dummy variables are calculated by $\Phi\left(\mathrm{X}_{1} \mathrm{~b}\right)-\Phi\left(\mathrm{X}_{0} \mathrm{~b}\right)$, where $\Phi$ is the cumulative normal density, and $\mathrm{X}_{0}$ and $\mathrm{X}_{1}$ are vectors of the means of the independent variables except that the value of the dummy variable of interest equals 0 and 1, respectively. Marginal effects for continuous variables are calculated at the means of the independent variables.

In using a set of alcohol regulatory variables, one must be concerned with the potential problems of omitted variable bias and multicollinearity. Including all the relevant control variables, as shown in Tables 2-4, may lead to multicollinearity. This problem would arise if countries which have high anti-drinking sentiment impose higher taxes on alcohol and place more restrictions on availability. Omitting the regulatory variables, however, may lead to omitted variable bias if the regulatory measures are predictors of violence. Models were tested without the blood alcohol level, the advertising ban, and the minimum legal drinking age, but the results were very similar to those presented in Tables 2-4.

It should be cautioned that the prices of alcohol contain measurement error for two reasons. The first is simply that the price and tax are calculated, rather than observed directly, and second, individuals are assigned country specific prices rather than area specific prices. Random measurement error in an independent variable biases its coefficient and t-ratio towards zero. Thus, the price coefficients and associated t-ratios are considered conservative lowerbound estimates. $^{9}$

\section{RESULTS}

The results of the reduced form equations are presented in Tables 2-4. Table 2 shows the 
effects of the alcohol regulatory variables and individual characteristics on the probability of being a victim of robbery. Beginning with the models that include the price (columns 1 and 2), the results show that the price coefficient is negative and statistically significant only in the model which excludes the country dummies (column 1 ). ${ }^{10}$ Once the country dummies are added, the price coefficient becomes positive and insignificant. A serious problem with the models that include the country dummies is that they suffer from multicollinearity in that the price is highly correlated with the country dummies. The r-squared from a regression of the price on the country dummies is 0.99 indicating that the country dummies explain practically all of the variation in the price. Adding a set of variables which are highly correlated with an existing variable can result in wide swings in the magnitude, sign and significance of the variable.

Columns 3 and 4 show the results of the reduced form violence equation with the tax included rather than the price. The results of the tax coefficient are very similar to that of the price. Without the country dummies (column 3 ) the coefficient on the tax is negative and significant indicating that an increase in the tax on alcohol will lower the probability of being a victim of robbery. However, once the country dummies are added, the coefficient on the tax remains negative, but becomes statistically insignificant. As with the price, most of the variation in the tax variable can be explained by the country dummies. The r-squared from a regression of the tax on the country dummies is 0.99 .

The models in columns 1 and 3 also include other alcohol regulatory variables. The results indicate that higher legal blood alcohol levels will lead to more robbery, while prohibitions on advertising will lead to less robbery. The coefficient on the legal minimum legal drinking age is negative as expected, however, it is only statistically significant at the 10 percent level when the tax is included (column 3). The blood alcohol level is the only regulatory 
variable included with the country dummies (see columns 2 and 4). Here, increases in the blood alcohol level have no effect on the probability of robbery.

Some of the individual characteristics affect the likelihood of being a victim of robbery. Women and older people are less likely to be victims, while people who go out frequently at night or who live in large communities are more likely to be victims. Employment status and income have no effects on the probability of being robbed. These results hold both with the price and the tax included.

In Table 3, the probability of being assaulted is the dependent variable. The conclusions are strikingly similar to the models where robbery is the dependent variable. When the price or tax is included with the full set of countries, the coefficient is negative and significant (columns 1 and 3). When the country dummies are added (columns 2 and 4), the coefficient on the price becomes positive and insignificant, and the coefficient on the tax becomes negative and insignificant.

In columns 1 and 3 of Table 3, while both the advertising and minimum legal drinking age coefficients are statistically significant, neither displays the anticipated sign. However, the blood alcohol level is positive as expected, and is statistically significant in column 3 when the tax is included. Next, the same individual characteristics which affect the probability of robbery also affect the probability of being assaulted. Women and older people are less likely to be victims, while people who go out frequently at night and people who live in large communities are more likely to be victims. Employment status has no effect on the probability of being assaulted, but in the models with all countries included (columns 1 and 3), having income higher than the median for the country is associated with a lower probability of assault. This finding does not remain statistically significant once the country dummies are included. 
Finally, Table 4 shows the results of the probability of females being victims of sexual assault. As with robbery and assault, increases in both measures of the price of alcohol will serve to reduce the probability of sexual assault against women when the country dummies are excluded (columns 1 and 3). The ability of the other alcohol regulatory variables to reduce the probability of sexual assault is unclear. Only the coefficient on the prohibition of advertising has the anticipated sign, and this is only significant in column 1. The blood alcohol level and the minimum legal drinking age are statistically significant, but the sign is not in the anticipated direction. Including the country dummies makes the coefficient on the blood alcohol level insignificant.

The individual characteristics that affect the probability of sexual assault are the same as those that affect both robbery and assault. In addition, high income is associated with a lower probability of sexual assault, and this result holds across all models. Finally, women who report occupation as other (which includes homemakers, retirees, and women the armed services) or are unemployed (when the country dummies are excluded) have a lower probability of being sexually assaulted as compared to other women who work full time, part time, or are students.

\section{$\underline{\text { VII. DISCUSSION }}$}

Using data from the 1989 and 1992 International Victimization Surveys, this paper shows some evidence that increasing the price of alcohol can be an effective policy tool in reducing violent crime. That is, rates of robbery, assault, and sexual assault against women can be lowered by increasing either the price of alcoholic beverages or by increasing the tax on alcoholic beverages. Controlling for country fixed effects does not allow for precise estimates of the price or tax on the probability of violence because of severe collinearity between the price 
measures and the country dummies. Clearly, a longer time series or different measures of the price of alcohol would be needed in order to separate out the effects of country level unobservables from the price measures.

Estimates from models which exclude country fixed effects reveal that the magnitude of increases in the price of alcohol in reducing crime may be very small. Elasticities are calculated by multiplying the marginal effect of the coefficient to the ratio of the average price to the average crime rate. A one percent increase in the calculated price of alcohol will lead to a 0.27 percent decrease in the probability of robbery, a 0.30 percent decrease in the probability of assault and a 0.21 percent decrease in the probability of sexual assault. Similarly, a one percent increase in the calculated tax on alcohol will cause the probabilities of robbery, assault, and sexual assault to fall by 0.19 percent, 0.25 percent and 0.16 percent, respectively.

Other regulatory variables may have some negative effects on crime, however, the conclusions are not consistent across the different types of violent crime. Lower legal blood alcohol levels, advertising bans, and higher minimum legal drinking ages will lower the probability of robbery. Lower legal blood alcohol levels may also reduced the probability of assault, but neither advertising bans nor higher minimum legal drinking ages will reduce the probability of assault or sexual assault against women. 


\section{FOOTNOTES}

This paper was presented at the Allied Social Sciences Associating meeting in New York, NY, January 3-5, 1999 and at the Taipei International Conference on Health Economics organized by the Institute of Economics, Academia Sinica in Taipei, Taiwan, March 25-26, 1999. I would like to thank Phil Cook, Michael Grossman, Ya-Chen Tina Shih and the conference participants for helpful comments and suggestions. Research for this paper was supported by grant number 1 R01 AA10817 from the National Institute on Alcohol Abuse and Alcoholism to the NBER. This paper has not undergone the review accorded official NBER publications; in particular, it has not been submitted for approval by the Board of Directors. Any opinions expressed are those of the authors and not that of NIAAA or the NBER.

${ }^{1}$ From an economics standpoint, this second theory translates into using alcohol as a way of lowering the probability of facing penalties. Becker (1968) shows that the criminal's choice level of crime is determined by weighting the probable costs and benefits of crime. Alcohol use may decrease the probability of facing penalties if the victim or the courts are less willing to impose costs on criminals who drink. This may occur if the criminal's behavior is deemed to be out of his or her control and is a result of being under the influence of alcohol. See Markowitz and Grossman (1998b) for a complete derivation of a model in which alcohol affects the probability of facing penalties. Note that this last argument may only hold for violent criminals. Criminals who commit property crimes may be more likely to be caught and face penalties when drinking if the drinking causes them to be more careless while committing the crime (Cordilia, 1985). 
${ }^{2}$ Law enforcement variables are omitted from the models presented in this paper because comparable cross country data on police and other criminal justice measures are not available. In addition, including law enforcement measures would lead to biased estimates because these measures would be endogenous in the violence equation. The fixed effect models presented below do help account for such unmeasured variables.

3 There may be an offsetting effect in that in areas with low crime rates, victims may have less incentive to protect themselves against crimes. In this situation, an increase in the price would still lower both parties' consumption, but the fall in violence would allow victims to be less defensive and perhaps consume more. This situation would only serve to weaken the negative price effect.

4 "The purchasing power parities (PPPs) are rates of currency conversion that enable the expression of the purchasing power of different currencies in a common unit. In other words, a given sum of money, when converted at the PPP rates, will buy the same basket of goods and services in all countries. Thus PPPs are the rates of currency conversion which eliminate differences in price levels among countries." (OECD, 1993, p. 8) Prices deflated by the PPP are real prices expressed in U.S. dollars at a moment in time. These must be deflated by the U.S. GDP deflator in order to make comparisons over time. To spell this out in more detail, let $\mathrm{p}_{\mathrm{jt}}$ be the price of alcohol in country $\mathrm{j}$ in year $\mathrm{t}$ expressed in country j's currency. Let $\mathrm{e}_{\mathrm{jt}}$ be the nominal exchange rate expressed as country j's currency per U.S. dollar. Then $\mathrm{p}_{\mathrm{jt}} / \mathrm{e}_{\mathrm{jt}}$ is the nominal price of alcohol in country $\mathrm{j}$ in U.S. dollars. Let $\mathrm{r}_{\mathrm{jt}}$ be purchasing power parity expressed as country j's currency per U.S. dollars. Then $\mathrm{r}_{\mathrm{jt}} / \mathrm{e}_{\mathrm{jt}}$ is a cost of living index that reflects differences in the cost of living between the two countries at a moment in time. Hence the real price of alcohol $\left(\pi_{\mathrm{jt}}\right)$ at a moment in time in U.S. dollars is 


$$
\pi_{\mathrm{jt}}=\left[\left(\mathrm{p}_{\mathrm{jt}} / \mathrm{e}_{\mathrm{jt}}\right)\right] /\left[\left(\mathrm{r}_{\mathrm{jt}} / \mathrm{e}_{\mathrm{jt}}\right)\right]=\mathrm{p}_{\mathrm{jt}} / \mathrm{r}_{\mathrm{jt}}
$$

Note that the nominal exchange rate drops out of the above formula. With data for only a single year, no other computations would be required. But cross sections of countries in two different years are employed. Hence the real price that reflects variations over time within countries as well as variations at a moment in time among countries $\left(\mathrm{z}_{\mathrm{jt}}\right)$ is

$$
\mathrm{Z}_{\mathrm{jt}}=\mathrm{p}_{\mathrm{jt}} / \mathrm{r}_{\mathrm{jt}} \mathrm{c}_{\mathrm{ut}}
$$

where $\mathrm{c}_{\mathrm{ut}}$ is the U.S. GDP deflator in year $\mathrm{t}$ relative to year 0 since the real price at a moment in time is in U.S. dollars.

${ }^{5}$ Models were tested that include a separate variable indicating that 75 percent or more of a country's consumption comes from beer or wine. Including this variable did not alter the results.

${ }^{6}$ All countries that ban beer and wine advertisements on radio and television also ban liquor advertisements. The converse is not always true.

${ }^{7}$ Models were tested that limit the set of countries to only those that are in both years of the survey, but omit the country fixed effects. Results were very similar to those for the full set of countries presented in Tables 2-4.

8 The United States is the omitted country category.

${ }^{9}$ A comparison of the calculated price of alcohol for the United States to a similar price created from the American Chamber of Commerce Researchers Association's Cost of Living Index shows the prices are fairly close in magnitude. ( $\$ 0.61$ and $\$ 0.72$ versus $\$ 0.72$ and $\$ 0.79$ for 1988 and 1991, respectively.)

${ }^{10}$ Statistical significance refers to a two-tailed test at the 5 percent level. 


\section{REFERENCES}

American Chamber of Commerce Research Association. Inter-City Cost of Living Index. Louisville, KY: ACCRA, various years.

Brewers Association of Canada, Alcoholic Beverage Taxation and Control Policies. 1997.

Becker, Gary S. "Crime and Punishment: An Economic Approach." Journal of Political Economy, 76:2 March/April 1968, 169-217.

Bureau of Justice Statistics, U.S. Department of Justice. Report to the Nation on Crime and Justice. Second Edition. NCJ-105506, March 1988.

Chaloupka, Frank J., and Henry Saffer. "Alcohol, Illegal Drugs, Public Policy and Crime." Presented at the annual meeting of the Western Economic Association, San Francisco, CA, July 1992.

Cook, Philip J., and Moore, Michael J. "Economic Perspectives on Reducing Alcohol-Related Violence." In Alcohol and Interpersonal Violence: Fostering Multidisciplinary Perspectives, edited by Susan E. Martin. National Institute on Alcohol Abuse and Alcoholism Research Monograph 24. NIH Publication No.93-3469, U.S. Government Printing Office, Washington, DC, 1993, 193-211.

Cordilia, A., "Alcohol and Property Crime: Explaining the Causal Nexus." Journal of Studies on Alcohol, 46:2, March 1985, 161-171.

Dolan, Ronald E. and Robert L. Worden, Editors. Japan, A Country Study. Federal Research Division, Library of Congress, January, 1994.

Fagan, Jeffrey. "Intoxication and Aggression" in Drugs and Crime: Crime and Justice, A Review of Research, Vol. 13. Michael Tonry and James Q. Wilson, Editors. The University of Chicago Press, Chicago, 1990.

Fagan, Jeffrey. "Interactions Among Drugs, Alcohol and Violence." Health Affairs, 12:4, Winter 1993, 65-79.

Grossman, Michael, Frank J. Chaloupka and Ismail Sirtalan. "An Empirical Analysis of Alcohol Addiction: Results from the Monitoring the Future Panels." Economic Inquiry, 36:1, January 1998, 39-48.

Grossman, Michael and Sara Markowitz. "Alcohol Regulation and Violence on College Campuses." Presented at the Taipei International Conference on Health Economics, Taipei, Taiwan, March 25-26, 1999. 
Johnson, S.D., L. Gibson, and R. Linden. "Alcohol and Rape in Winnipeg, 1966-1975" Journal of Studies on Alcohol. 39:11, 1978, 1887-1894.

Kenkel, Donald S. "Drinking, Driving, and Deterrence: The Effectiveness and Social Costs of Alternative Policies." Journal of Law and Economics, October, 1993, 877-913.

Lenke, L. "Valdbrott och alkohol: En studie I misshandelsbrottslighentens utvekling [Violent Crime and Alcohol: A Study of the Developments in Assaultive Crime]". Stockholm: Department of Criminology, University of Stockholm, 1975.

Leung, Siu Fai and Charles E. Phelps. "My Kingdom for a Drink....?' A Review of the Price Sensitivity of Demand for Alcoholic Beverages" in Economic and Socioeconomic Issues in the Prevention of Alcohol-Related Problems. Gregory Bloss and Michael Hilton, Editors. U.S. Government Printing Office, 1993.

Lindqvist, P. "Criminal Homicide in Northern Sweden 1970-1981: Alcohol Intoxication, Alcohol Abuse and Mental Disease." International Journal of Law and Psychiatry. 8, 1986, 19-37.

Manning, Willard G., Linda Blumberg and Lawrence H. Moulton. "The Demand for Alcohol: the Differential Response to Price.” Journal of Health Economics, 14:2, June 1995, 123148.

Markowitz, Sara, "The Price of Alcohol, Wife Abuse and Husband Abuse", National Bureau of Economic Research Working Paper No. 6916, January 1999.

Markowitz, Sara and Michael Grossman. "Alcohol Regulation and Domestic Violence Towards Children." Contemporary Economic Policy, 16: 309-320, 1998 a.

Markowitz, Sara and Michael Grossman. "The Effects of Alcohol Regulation on Physical Child Abuse.” National Bureau of Economic Research Working Paper No. 6629, July 1998b.

Miczek, K.A., J.F. DeBold, M. Haney, J.Tidey, J. Vivian, and E.M. Weerts. "Alcohol, Drugs of Abuse, Aggression, and Violence" in Understanding and Preventing Violence, Volume 3. Albert J. Reiss and Jeffery A. Roth, editors. National Academy Press, Washington, D.C.: 1994.

Myers, T. "Alcohol and Violent Crime Re-examined: Self-reports from two Sub-groups of Scottish Male Prisoners." British Journal of Addiction. 77, 1982, 399-413.

Myers, T. "An Analysis of Context and Alcohol Consumption in a Group of Criminal Events." Alcohol and Alcoholism. 21, 1986, 389-395. 
National Research Council. Understanding and Preventing Violence. Reiss, Albert J., and Jeffery A. Roth, Editors. National Academy Press, Washington, D.C., 1993.

OECD. Health Data, [Computer data file], 1997.

OECD. OECD Health Systems: The Socio-economic Environment Statistical References. Paris, France, 1993.

Pernanen, Kai. "Theoretical Aspects of the Relationship Between Alcohol Use and Crime." in Drinking and Crime: Perspectives on the Relationships between Alcohol Consumption and Criminal Behavior. James J. Collins Jr., editor. The Guilford Press, New York, NY, 1981.

Roslund, B. and C.A. Larson. "Crimes of Violence and Alcohol Abuse in Sweden" International Journal of the Addictions, 14:8, 1979, 1103-1115.

Saffer, Henry. "Alcohol Advertising Bans and Alcohol Abuse: An International Perspective". Journal of Health Economics, 10:1, 1991, 65-79.

Sampson, Robert J. and Janet L. Lauritsen, "Violent Victimization and Offending: IndividualSituational- and Community-Level Risk Factors" in Understanding and Preventing Violence, Volume 3. Albert J. Reiss and Jeffery A. Roth, editors. National Academy Press, Washington, D.C.: 1994.

Takala, H. "Alkoholstrejkens inverkan pa uppdagad brottslighet [The Effect of the Alcohol Strike on Reported Crime.]" Alkoholpolitik, 1973, 36, 14-16.

Virkkunen, M. "Alcohol as a Factor Precipitating Aggression and Conflict of Behaviour Leading to Homicide." British Journal of Addiction. 69, 1974, 149-154. 
Table 1

Means

\begin{tabular}{|c|c|c|c|c|c|c|c|}
\hline Country & Year & $\begin{array}{c}\text { Number of } \\
\text { observations }\end{array}$ & Robbery & Assault & $\begin{array}{l}\text { Sexual } \\
\text { assault }\end{array}$ & $\begin{array}{l}\text { Price of } \\
\text { alcohol }\end{array}$ & $\begin{array}{l}\text { Tax on } \\
\text { alcohol }\end{array}$ \\
\hline \multirow[t]{2}{*}{ Australia } & 1988 & 2,012 & 0.006 & 0.048 & 0.069 & 1.526 & 0.446 \\
\hline & 1991 & 2,006 & 0.011 & 0.042 & 0.032 & 1.627 & 0.547 \\
\hline \multirow[t]{2}{*}{ Belgium } & 1988 & 2,060 & 0.009 & 0.020 & 0.012 & 0.413 & 0.015 \\
\hline & 1991 & 1,485 & 0.009 & 0.017 & 0.011 & 0.456 & 0.016 \\
\hline \multirow[t]{2}{*}{ Canada } & 1988 & 2,074 & 0.013 & 0.044 & 0.041 & 1.301 & 0.264 \\
\hline & 1991 & 2,152 & 0.012 & 0.049 & 0.037 & 1.315 & 0.307 \\
\hline \multirow[t]{2}{*}{ Finland } & 1988 & 1,025 & 0.004 & 0.025 & 0.005 & 1.454 & 1.122 \\
\hline & 1991 & 1,655 & 0.009 & 0.039 & 0.030 & 1.526 & 1.085 \\
\hline France & 1988 & 1,502 & 0.005 & 0.021 & 0.012 & 0.466 & 0.099 \\
\hline Germany & 1988 & 5,274 & 0.008 & 0.035 & 0.034 & 0.576 & 0.129 \\
\hline Italy & 1991 & 2,024 & 0.013 & 0.007 & 0.016 & 0.419 & 0.044 \\
\hline Japan & 1988 & 2,411 & 0.000 & 0.005 & 0.011 & 4.087 & 0.456 \\
\hline \multirow[t]{2}{*}{ Netherlands } & 1988 & 2,000 & 0.007 & 0.035 & 0.025 & 0.522 & 0.214 \\
\hline & 1991 & 2,000 & 0.010 & 0.029 & 0.023 & 0.533 & 0.192 \\
\hline New Zealand & 1991 & 2,048 & 0.005 & 0.047 & 0.027 & 0.631 & 0.304 \\
\hline Norway & 1988 & 1,009 & 0.005 & 0.028 & 0.018 & 1.962 & 1.037 \\
\hline \multirow[t]{2}{*}{ Spain } & 1988 & 2,041 & 0.029 & 0.031 & 0.023 & 0.290 & 0.159 \\
\hline & 1991 & 1,634 & 0.032 & 0.019 & 0.013 & 0.312 & 0.205 \\
\hline Sweden & 1991 & 1,707 & 0.004 & 0.026 & 0.012 & 1.461 & 0.764 \\
\hline Switzerland & 1988 & 1,000 & 0.002 & 0.009 & 0.012 & 2.176 & 0.088 \\
\hline \multirow[t]{2}{*}{ United Kingdom } & 1988 & 6,013 & 0.005 & 0.018 & 0.014 & 2.522 & 0.610 \\
\hline & 1991 & 2,001 & 0.009 & 0.034 & 0.019 & 2.585 & 0.554 \\
\hline \multirow[t]{2}{*}{ United States } & 1988 & 1,996 & 0.019 & 0.052 & 0.045 & 0.768 & 0.184 \\
\hline & 1991 & 1,501 & 0.015 & 0.044 & 0.024 & 0.837 & 0.202 \\
\hline \multirow[t]{2}{*}{ All countries } & 1988 & 30,417 & 0.009 & 0.029 & 0.025 & 1.453 & 0.345 \\
\hline & 1991 & 20,213 & 0.012 & 0.032 & 0.022 & 1.085 & 0.382 \\
\hline
\end{tabular}


Table 2

Robbery

\begin{tabular}{|c|c|c|c|c|}
\hline & $\begin{array}{c}\text { All countries } \\
\text { (1) }\end{array}$ & $\begin{array}{c}\text { Only countries } \\
\text { in both years } \\
\text { (2) }\end{array}$ & $\begin{array}{l}\text { All countries } \\
\text { (3) }\end{array}$ & $\begin{array}{c}\text { Only countries } \\
\text { in both years } \\
\text { (4) }\end{array}$ \\
\hline Price & $\begin{array}{l}-0.127 \\
(-4.14) \\
-0.002\end{array}$ & $\begin{array}{c}0.154 \\
(0.08) \\
\boldsymbol{0 . 0 0 3}\end{array}$ & & \\
\hline Tax & & & $\begin{array}{c}-0.263 \\
(-2.50) \\
\mathbf{- 0 . 0 0 5}\end{array}$ & $\begin{array}{c}-1.191 \\
(-0.62) \\
\mathbf{- 0 . 0 2 6}\end{array}$ \\
\hline Percentage of consumption from wine & $\begin{array}{r}0.293 \\
(1.84) \\
\boldsymbol{0 . 0 0 5}\end{array}$ & $\begin{array}{c}0.921 \\
(0.23) \\
\mathbf{0 . 0 2 0}\end{array}$ & $\begin{array}{c}0.361 \\
(2.23) \\
\boldsymbol{0 . 0 0 7}\end{array}$ & $\begin{array}{c}-2.175 \\
(-0.35) \\
-0.047\end{array}$ \\
\hline Percentage of consumption from liquor & $\begin{array}{c}1.513 \\
(3.85) \\
\mathbf{0 . 0 2 8}\end{array}$ & $\begin{array}{c}0.439 \\
(0.11) \\
\boldsymbol{0 . 0 0 9}\end{array}$ & $\begin{array}{c}1.962 \\
(5.23) \\
\boldsymbol{0 . 0 3 8}\end{array}$ & $\begin{array}{c}0.576 \\
(0.15) \\
\boldsymbol{0 . 0 1 2}\end{array}$ \\
\hline Blood alcohol level & $\begin{array}{c}6.362 \\
(4.65) \\
0.117\end{array}$ & $\begin{array}{c}0.350 \\
(0.08) \\
\boldsymbol{0 . 0 0 8}\end{array}$ & $\begin{array}{c}6.651 \\
(4.96) \\
0.127\end{array}$ & $\begin{array}{c}-1.615 \\
(-0.36) \\
\mathbf{- 0 . 0 3 5}\end{array}$ \\
\hline Advertising prohibited & $\begin{array}{c}-0.234 \\
(-3.37) \\
-0.004\end{array}$ & & $\begin{array}{c}-0.195 \\
(-2.86) \\
-\mathbf{0 . 0 0 3}\end{array}$ & \\
\hline Minimum legal drinking age & $\begin{array}{l}-0.009 \\
(-0.94) \\
-0.0002\end{array}$ & & $\begin{array}{l}-0.017 \\
(-1.80) \\
-0.0003\end{array}$ & \\
\hline Per capita income & $\begin{array}{l}-0.027 \\
(-3.20) \\
-0.0005\end{array}$ & $\begin{array}{c}-0.035 \\
(-0.66) \\
-0.001\end{array}$ & $\begin{array}{c}-0.034 \\
(-3.62) \\
-0.001\end{array}$ & $\begin{array}{c}-0.027 \\
(-0.57) \\
-0.001\end{array}$ \\
\hline Female & $\begin{array}{l}-0.075 \\
(-2.02) \\
-0.001\end{array}$ & $\begin{array}{c}-0.115 \\
(-2.70) \\
\mathbf{- 0 . 0 0 3}\end{array}$ & $\begin{array}{c}-0.074 \\
(-2.00) \\
-0.001\end{array}$ & $\begin{array}{c}-0.114 \\
(-2.67) \\
-0.003\end{array}$ \\
\hline Age & $\begin{array}{l}-0.010 \\
(-7.63) \\
-0.0002\end{array}$ & $\begin{array}{l}-0.014 \\
(-9.14) \\
-0.0003\end{array}$ & $\begin{array}{l}-0.010 \\
(-7.61) \\
-0.0002\end{array}$ & $\begin{array}{l}-0.014 \\
(-9.11) \\
-\mathbf{0 . 0 0 0 3}\end{array}$ \\
\hline High income & $\begin{array}{l}-0.025 \\
(-0.62) \\
-0.0005\end{array}$ & $\begin{array}{c}-0.025 \\
(-0.54) \\
-0.001\end{array}$ & $\begin{array}{l}-0.024 \\
(-0.61) \\
-0.0005\end{array}$ & $\begin{array}{c}-0.026 \\
(-0.56) \\
-0.001\end{array}$ \\
\hline Frequency goes out & $\begin{array}{l}0.0005 \\
(3.34) \\
\mathbf{0 . 0 0 0 0 1}\end{array}$ & $\begin{array}{l}0.001 \\
(3.10) \\
\mathbf{0 . 0 0 0 0 1}\end{array}$ & $\begin{array}{l}0.0005 \\
(3.33) \\
\mathbf{0 . 0 0 0 0 1}\end{array}$ & $\begin{array}{l}0.001 \\
(3.13) \\
\mathbf{0 . 0 0 0 0 1}\end{array}$ \\
\hline Town size & $\begin{array}{c}0.090 \\
(8.48) \\
0.002\end{array}$ & $\begin{array}{r}0.089 \\
(6.77) \\
0.002\end{array}$ & $\begin{array}{c}0.093 \\
(8.86) \\
\boldsymbol{0 . 0 0 2}\end{array}$ & $\begin{array}{r}0.088 \\
(6.77) \\
\boldsymbol{0 . 0 0 2}\end{array}$ \\
\hline 1991 & $\begin{array}{c}0.111 \\
(2.45) \\
0.002\end{array}$ & $\begin{array}{r}0.047 \\
(0.41) \\
\boldsymbol{0 . 0 0 1}\end{array}$ & $\begin{array}{c}0.140 \\
(3.19) \\
\boldsymbol{0 . 0 0 3}\end{array}$ & $\begin{array}{c}0.060 \\
(0.70) \\
\boldsymbol{0 . 0 0 1}\end{array}$ \\
\hline Part time work & $\begin{array}{c}-0.068 \\
(-0.91) \\
-0.001\end{array}$ & $\begin{array}{c}-0.044 \\
(-0.52) \\
-0.001\end{array}$ & $\begin{array}{c}-0.069 \\
(-0.93) \\
-0.001\end{array}$ & $\begin{array}{c}-0.044 \\
(-0.52) \\
-0.001\end{array}$ \\
\hline Unemployed & $\begin{array}{c}0.039 \\
(0.76) \\
\boldsymbol{0 . 0 0 1}\end{array}$ & $\begin{array}{c}0.011 \\
(0.17) \\
\mathbf{0 . 0 0 0 2}\end{array}$ & $\begin{array}{c}0.039 \\
(0.76) \\
\boldsymbol{0 . 0 0 1}\end{array}$ & $\begin{array}{c}0.009 \\
(0.14) \\
\mathbf{0 . 0 0 0 2}\end{array}$ \\
\hline Student & $\begin{array}{c}0.072 \\
(0.82) \\
\mathbf{0 . 0 0 1}\end{array}$ & $\begin{array}{r}0.087 \\
(0.84) \\
\boldsymbol{0 . 0 0 2}\end{array}$ & $\begin{array}{r}0.072 \\
(0.83) \\
\mathbf{0 . 0 0 2}\end{array}$ & $\begin{array}{c}0.084 \\
(0.82) \\
\boldsymbol{0 . 0 0 2}\end{array}$ \\
\hline
\end{tabular}


Table 2 (continued)

Other occupation

Australia

Belgium

Canada

Finland

Netherlands

Spain

United Kingdom

Chi-squared on country dummies

$$
\mathrm{N}
$$

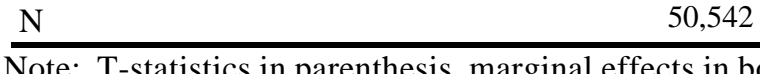
intercept not shown.

\begin{tabular}{|c|c|c|c|}
\hline \multirow{3}{*}{$\begin{array}{c}0.083 \\
(1.19) \\
0.002\end{array}$} & 0.147 & 0.073 & 0.140 \\
\hline & (1.77) & $(1.06)$ & (1.66) \\
\hline & 0.004 & 0.002 & 0.003 \\
\hline & $\begin{array}{c}-0.766 \\
(-0.51) \\
-\mathbf{0 . 0 0 9}\end{array}$ & & $\begin{array}{c}0.131 \\
(0.09) \\
\boldsymbol{0 . 0 0 3}\end{array}$ \\
\hline & $\begin{array}{c}-0.357 \\
(-0.34) \\
-0.006\end{array}$ & & $\begin{array}{c}-0.135 \\
(-0.17) \\
-0.003\end{array}$ \\
\hline & $\begin{array}{c}-0.435 \\
(-0.49) \\
-0.007\end{array}$ & & $\begin{array}{c}-0.208 \\
(-0.64) \\
-0.004\end{array}$ \\
\hline & $\begin{array}{c}-0.661 \\
(-0.57) \\
-0.008\end{array}$ & & $\begin{array}{r}0.497 \\
(0.28) \\
\boldsymbol{0 . 0 1 8}\end{array}$ \\
\hline & $\begin{array}{c}-0.465 \\
(-0.53) \\
-0.007\end{array}$ & & $\begin{array}{c}-0.202 \\
(-0.28) \\
-0.004\end{array}$ \\
\hline & $\begin{array}{c}-0.300 \\
(-0.18) \\
-0.005\end{array}$ & & $\begin{array}{c}0.633 \\
(0.30) \\
\mathbf{0 . 0 2 6}\end{array}$ \\
\hline & $\begin{array}{c}-0.858 \\
(-0.26) \\
-0.012\end{array}$ & & $\begin{array}{c}0.182 \\
(0.14) \\
\mathbf{0 . 0 0 4}\end{array}$ \\
\hline & $\begin{array}{c}5.136 \\
{[0.643]}\end{array}$ & & $\begin{array}{l}10.682 \\
{[0.153]}\end{array}$ \\
\hline 50,542 & 33,585 & 50,542 & 33,585 \\
\hline
\end{tabular}


Table 3

Assault

\begin{tabular}{|c|c|c|c|c|}
\hline & $\begin{array}{l}\text { All countries } \\
\text { (1) }\end{array}$ & $\begin{array}{c}\text { Only countries } \\
\text { in both years } \\
\text { (2) }\end{array}$ & $\begin{array}{l}\text { All countries } \\
\text { (3) }\end{array}$ & $\begin{array}{c}\text { Only countries } \\
\text { in both years } \\
(4)\end{array}$ \\
\hline Price & $\begin{array}{l}-0.120 \\
(-6.60) \\
-0.007\end{array}$ & $\begin{array}{c}1.224 \\
(0.99) \\
\boldsymbol{0 . 0 7 4}\end{array}$ & & \\
\hline $\operatorname{Tax}$ & & & $\begin{array}{l}-0.213 \\
(-3.42) \\
-0.012\end{array}$ & $\begin{array}{l}-2.023 \\
(-1.57) \\
-0.123\end{array}$ \\
\hline Percentage of consumption from wine & $\begin{array}{l}-1.160 \\
(-9.80) \\
-\mathbf{0 . 0 6 3}\end{array}$ & $\begin{array}{c}8.438 \\
(3.43) \\
\mathbf{0 . 5 1 3}\end{array}$ & $\begin{array}{c}-1.203 \\
(-9.38) \\
\mathbf{- 0 . 0 6 6}\end{array}$ & $\begin{array}{c}3.178 \\
(0.78) \\
0.193\end{array}$ \\
\hline Percentage of consumption from liquor & $\begin{array}{c}-0.521 \\
(-2.15) \\
-0.028\end{array}$ & $\begin{array}{c}3.228 \\
(1.42) \\
0.196\end{array}$ & $\begin{array}{l}-0.120 \\
(-0.50) \\
-0.007\end{array}$ & $\begin{array}{c}3.355 \\
(1.47) \\
\mathbf{0 . 2 0 4}\end{array}$ \\
\hline Blood alcohol level & $\begin{array}{r}0.984 \\
(1.23) \\
\mathbf{0 . 0 5 3}\end{array}$ & $\begin{array}{c}5.175 \\
(1.80) \\
\mathbf{0 . 3 1 4}\end{array}$ & $\begin{array}{c}2.166 \\
(2.84) \\
0.119\end{array}$ & $\begin{array}{c}0.389 \\
(0.13) \\
\mathbf{0 . 0 2 4}\end{array}$ \\
\hline Advertising prohibited & $\begin{array}{c}0.071 \\
(1.79) \\
\mathbf{0 . 0 0 4}\end{array}$ & & $\begin{array}{c}0.138 \\
(3.62) \\
\boldsymbol{0 . 0 0 8}\end{array}$ & \\
\hline Minimum legal drinking age & $\begin{array}{r}0.029 \\
(4.49) \\
\mathbf{0 . 0 0 2}\end{array}$ & & $\begin{array}{c}0.016 \\
(2.66) \\
0.001\end{array}$ & \\
\hline Per capita income & $\begin{array}{c}-0.015 \\
(-2.60) \\
\mathbf{- 0 . 0 0 1}\end{array}$ & $\begin{array}{l}-0.137 \\
(-3.71) \\
-0.008\end{array}$ & $\begin{array}{l}-0.023 \\
(-3.37) \\
-0.001\end{array}$ & $\begin{array}{l}-0.150 \\
(-4.54) \\
-0.009\end{array}$ \\
\hline Female & $\begin{array}{c}-0.091 \\
(-3.69) \\
-\mathbf{0 . 0 0 5}\end{array}$ & $\begin{array}{c}-0.080 \\
(-2.75) \\
-\mathbf{0 . 0 0 5}\end{array}$ & $\begin{array}{c}-0.091 \\
(-3.68) \\
\mathbf{- 0 . 0 0 5}\end{array}$ & $\begin{array}{c}-0.079 \\
(-2.71) \\
-\mathbf{0 . 0 0 5}\end{array}$ \\
\hline Age & $\begin{array}{c}-0.015 \\
(-16.98) \\
-\mathbf{0 . 0 0 1}\end{array}$ & $\begin{array}{c}-0.015 \\
(-14.15) \\
-\mathbf{0 . 0 0 1}\end{array}$ & $\begin{array}{c}-0.015 \\
(-17.02) \\
-\mathbf{0 . 0 0 1}\end{array}$ & $\begin{array}{c}-0.015 \\
(-14.12) \\
-\mathbf{0 . 0 0 1}\end{array}$ \\
\hline High income & $\begin{array}{c}-0.066 \\
(-2.54) \\
\mathbf{- 0 . 0 0 4}\end{array}$ & $\begin{array}{c}-0.045 \\
(-1.44) \\
-\mathbf{0 . 0 0 3}\end{array}$ & $\begin{array}{c}-0.066 \\
(-2.52) \\
\mathbf{- 0 . 0 0 4}\end{array}$ & $\begin{array}{c}-0.046 \\
(-1.46) \\
-\mathbf{0 . 0 0 3}\end{array}$ \\
\hline Frequency goes out & $\begin{array}{l}0.001 \\
(5.77) \\
\mathbf{0 . 0 0 0 0 3}\end{array}$ & $\begin{array}{l}0.001 \\
(5.03) \\
\mathbf{0 . 0 0 0 0 4}\end{array}$ & $\begin{array}{l}0.001 \\
(5.75) \\
\mathbf{0 . 0 0 0 0 3}\end{array}$ & $\begin{array}{l}0.001 \\
(5.03) \\
0.00004\end{array}$ \\
\hline Town size & $\begin{array}{r}0.051 \\
(7.06) \\
\mathbf{0 . 0 0 3}\end{array}$ & $\begin{array}{c}0.045 \\
(5.01) \\
\mathbf{0 . 0 0 3}\end{array}$ & $\begin{array}{c}0.058 \\
(8.10) \\
\mathbf{0 . 0 0 3}\end{array}$ & $\begin{array}{r}0.045 \\
(5.03) \\
\mathbf{0 . 0 0 3}\end{array}$ \\
\hline 1991 & $\begin{array}{l}-0.009 \\
(-0.30) \\
-0.0005\end{array}$ & $\begin{array}{c}0.019 \\
(0.27) \\
\boldsymbol{0 . 0 0 1}\end{array}$ & $\begin{array}{c}0.031 \\
(1.06) \\
0.002\end{array}$ & $\begin{array}{c}0.066 \\
(1.21) \\
0.004\end{array}$ \\
\hline Part time work & $\begin{array}{c}0.012 \\
(0.27) \\
\boldsymbol{0 . 0 0 1}\end{array}$ & $\begin{array}{c}0.010 \\
(0.19) \\
\mathbf{0 . 0 0 1}\end{array}$ & $\begin{array}{c}0.013 \\
(0.30) \\
\boldsymbol{0 . 0 0 1}\end{array}$ & $\begin{array}{c}0.007 \\
(0.14) \\
\mathbf{0 . 0 0 0 4}\end{array}$ \\
\hline Unemployed & $\begin{array}{c}-0.036 \\
(-1.04) \\
\mathbf{- 0 . 0 0 2}\end{array}$ & $\begin{array}{c}-0.038 \\
(-0.92) \\
\mathbf{- 0 . 0 0 2}\end{array}$ & $\begin{array}{c}-0.033 \\
(-0.96) \\
-0.002\end{array}$ & $\begin{array}{c}-0.039 \\
(-0.96) \\
-\mathbf{0 . 0 0 2}\end{array}$ \\
\hline Student & $\begin{array}{c}0.088 \\
(1.53) \\
\boldsymbol{0 . 0 0 5}\end{array}$ & $\begin{array}{c}0.092 \\
(1.33) \\
\boldsymbol{0 . 0 0 6}\end{array}$ & $\begin{array}{c}0.084 \\
(1.46) \\
\mathbf{0 . 0 0 5}\end{array}$ & $\begin{array}{c}0.086 \\
(1.25) \\
\boldsymbol{0 . 0 0 6}\end{array}$ \\
\hline
\end{tabular}


Table 3 (continued)

Other occupation

Australia

Belgium

Canada

Finland

Netherlands

Spain

United Kingdom

Chi-squared on country dummies

$\mathrm{N}$ intercept not shown.

\begin{tabular}{|c|c|c|c|}
\hline 0.003 & 0.014 & -0.010 & 0.006 \\
\hline$(0.07)$ & $(0.26)$ & $(-0.21)$ & $(0.11)$ \\
\hline 0.0002 & 0.001 & -0.001 & 0.0004 \\
\hline & $\begin{array}{c}-2.231 \\
(-2.40) \\
\mathbf{- 0 . 0 4 7}\end{array}$ & & $\begin{array}{c}-0.162 \\
(-0.18) \\
-0.009\end{array}$ \\
\hline & $\begin{array}{c}-1.183 \\
(-1.67) \\
-\mathbf{- 0 . 0 3 3}\end{array}$ & & $\begin{array}{c}-1.337 \\
(-2.62) \\
-\mathbf{- 0 . 0 3 5}\end{array}$ \\
\hline & $\begin{array}{c}-1.179 \\
(-2.10) \\
-\mathbf{0 . 0 3 5}\end{array}$ & & $\begin{array}{c}-0.409 \\
(-2.02) \\
-0.019\end{array}$ \\
\hline & $\begin{array}{c}-1.847 \\
(-2.54) \\
-\mathbf{0 . 0 3 6}\end{array}$ & & $\begin{array}{r}0.559 \\
(0.49) \\
\mathbf{0 . 0 5 3}\end{array}$ \\
\hline & $\begin{array}{c}-1.029 \\
(-1.70) \\
-\mathbf{0 . 0 3 2}\end{array}$ & & $\begin{array}{c}-1.046 \\
(-2.25) \\
\mathbf{- 0 . 0 3 3}\end{array}$ \\
\hline & $\begin{array}{c}-3.346 \\
(-2.94) \\
-0.057\end{array}$ & & $\begin{array}{c}-2.499 \\
(-1.88) \\
-\mathbf{0 . 0 4 7}\end{array}$ \\
\hline & $\begin{array}{c}-3.555 \\
(-1.72) \\
-0.137\end{array}$ & & $\begin{array}{c}-0.271 \\
(-0.32) \\
-0.014\end{array}$ \\
\hline & $\begin{array}{l}60.496 \\
{[0.000]}\end{array}$ & & $\begin{array}{l}78.557 \\
{[0.000]}\end{array}$ \\
\hline 50,464 & 33,521 & 50,464 & 33,521 \\
\hline
\end{tabular}
33,521 
Table 4

Sexual Assault Against Women

\begin{tabular}{|c|c|c|c|c|}
\hline & $\begin{array}{l}\text { All countries } \\
\text { (1) }\end{array}$ & $\begin{array}{c}\text { Only countries } \\
\text { in both years } \\
(2)\end{array}$ & $\begin{array}{l}\text { All countries } \\
\text { (3) }\end{array}$ & $\begin{array}{c}\text { Only countries } \\
\text { in both years } \\
\text { (4) }\end{array}$ \\
\hline Price & $\begin{array}{l}-0.116 \\
(-4.22) \\
-0.004\end{array}$ & $\begin{array}{c}1.282 \\
(0.66) \\
\boldsymbol{0 . 0 4 4}\end{array}$ & & \\
\hline Tax & & & $\begin{array}{c}-0.331 \\
(-3.28) \\
\mathbf{- 0 . 0 1 1}\end{array}$ & $\begin{array}{l}-3.278 \\
(-1.60) \\
-0.113\end{array}$ \\
\hline Percentage of consumption from wine & $\begin{array}{l}-0.719 \\
(-4.33) \\
-\mathbf{0 . 0 2 4}\end{array}$ & $\begin{array}{c}8.334 \\
(2.00) \\
\mathbf{0 . 2 8 9}\end{array}$ & $\begin{array}{l}-0.859 \\
(-4.72) \\
\mathbf{- 0 . 0 2 9}\end{array}$ & $\begin{array}{l}-0.142 \\
(-0.02) \\
-0.005\end{array}$ \\
\hline Percentage of consumption from liquor & $\begin{array}{l}-1.775 \\
(-4.94) \\
\mathbf{- 0 . 0 6 0}\end{array}$ & $\begin{array}{l}-8.599 \\
(-1.90) \\
-0.298\end{array}$ & $\begin{array}{l}-1.523 \\
(-4.29) \\
\mathbf{- 0 . 0 5 2}\end{array}$ & $\begin{array}{l}-8.428 \\
(-1.86) \\
-0.291\end{array}$ \\
\hline Blood alcohol level & $\begin{array}{l}-2.907 \\
(-2.37) \\
-\mathbf{0 . 0 9 9}\end{array}$ & $\begin{array}{r}6.194 \\
(1.33) \\
0.215\end{array}$ & $\begin{array}{l}-1.997 \\
(-1.76) \\
\mathbf{- 0 . 0 6 8}\end{array}$ & $\begin{array}{c}-0.318 \\
(-0.07) \\
-\mathbf{0 . 0 1 1}\end{array}$ \\
\hline Advertising prohibited & $\begin{array}{l}-0.148 \\
(-2.38) \\
\mathbf{- 0 . 0 0 4}\end{array}$ & & $\begin{array}{l}-0.089 \\
(-1.45) \\
-\mathbf{0 . 0 0 3}\end{array}$ & \\
\hline Minimum legal drinking age & $\begin{array}{c}0.063 \\
(6.18) \\
\boldsymbol{0 . 0 0 2}\end{array}$ & & $\begin{array}{c}0.055 \\
(5.76) \\
0.002\end{array}$ & \\
\hline Per capita income & $\begin{array}{c}0.010 \\
(1.11) \\
\mathbf{0 . 0 0 0 3}\end{array}$ & $\begin{array}{c}-0.127 \\
(-2.23) \\
\mathbf{- 0 . 0 0 4}\end{array}$ & $\begin{array}{c}-0.003 \\
(-0.28) \\
\boldsymbol{0 . 0 0 0}\end{array}$ & $\begin{array}{c}-0.140 \\
(-2.64) \\
\mathbf{- 0 . 0 0 5}\end{array}$ \\
\hline Age & $\begin{array}{c}-0.025 \\
(-16.57) \\
-\mathbf{0 . 0 0 1}\end{array}$ & $\begin{array}{c}-0.026 \\
(-14.12) \\
-\mathbf{0 . 0 0 1}\end{array}$ & $\begin{array}{c}-0.025 \\
(-16.50) \\
-\mathbf{0 . 0 0 1}\end{array}$ & $\begin{array}{c}-0.026 \\
(-14.09) \\
-\mathbf{0 . 0 0 1}\end{array}$ \\
\hline High income & $\begin{array}{c}-0.111 \\
(-2.82) \\
-\mathbf{0 . 0 0 4}\end{array}$ & $\begin{array}{c}-0.140 \\
(-2.93) \\
-\mathbf{0 . 0 0 5}\end{array}$ & $\begin{array}{c}-0.112 \\
(-2.86) \\
-0.004\end{array}$ & $\begin{array}{c}-0.141 \\
(-2.95) \\
\mathbf{- 0 . 0 0 5}\end{array}$ \\
\hline Frequency goes out & $\begin{array}{l}0.001 \\
(5.00) \\
\mathbf{0 . 0 0 0 0 3}\end{array}$ & $\begin{array}{l}0.001 \\
(3.93) \\
\mathbf{0 . 0 0 0 0 3}\end{array}$ & $\begin{array}{l}0.001 \\
(5.10) \\
\mathbf{0 . 0 0 0 0 3}\end{array}$ & $\begin{array}{l}0.001 \\
(3.98) \\
\mathbf{0 . 0 0 0 0 3}\end{array}$ \\
\hline Town size & $\begin{array}{c}0.064 \\
(5.90) \\
\mathbf{0 . 0 0 2}\end{array}$ & $\begin{array}{c}0.060 \\
(4.36) \\
\text { 0.002 }\end{array}$ & $\begin{array}{c}0.070 \\
(6.54) \\
\boldsymbol{0 . 0 0 2}\end{array}$ & $\begin{array}{r}0.059 \\
(4.31) \\
\boldsymbol{0 . 0 0 2}\end{array}$ \\
\hline 1991 & $\begin{array}{c}-0.103 \\
(-2.17) \\
\mathbf{- 0 . 0 0 3}\end{array}$ & $\begin{array}{c}-0.188 \\
(-1.54) \\
-0.006\end{array}$ & $\begin{array}{c}-0.061 \\
(-1.35) \\
\mathbf{- 0 . 0 0 2}\end{array}$ & $\begin{array}{c}-0.136 \\
(-1.41) \\
\mathbf{- 0 . 0 0 5}\end{array}$ \\
\hline Part time work & $\begin{array}{c}0.038 \\
(0.72) \\
\mathbf{0 . 0 0 1}\end{array}$ & $\begin{array}{c}0.089 \\
(1.36) \\
\mathbf{0 . 0 0 3}\end{array}$ & $\begin{array}{c}0.041 \\
(0.77) \\
\mathbf{0 . 0 0 1}\end{array}$ & $\begin{array}{c}0.086 \\
(1.33) \\
\mathbf{0 . 0 0 3}\end{array}$ \\
\hline Unemployed & $\begin{array}{c}-0.098 \\
(-1.94) \\
-\mathbf{0 . 0 0 3}\end{array}$ & $\begin{array}{c}-0.065 \\
(-1.05) \\
-0.002\end{array}$ & $\begin{array}{c}-0.092 \\
(-1.83) \\
-\mathbf{0 . 0 0 3}\end{array}$ & $\begin{array}{c}-0.066 \\
(-1.06) \\
-0.002\end{array}$ \\
\hline Student & $\begin{array}{l}-0.001 \\
(-0.01) \\
-0.00002\end{array}$ & $\begin{array}{c}0.006 \\
(0.06) \\
\mathbf{0 . 0 0 0 2}\end{array}$ & $\begin{array}{l}0.0001 \\
(0.001) \\
\mathbf{0 . 0 0 0 0 0 3}\end{array}$ & $\begin{array}{l}-0.003 \\
(-0.03) \\
-0.0001\end{array}$ \\
\hline Other occupation & $\begin{array}{c}-0.245 \\
(-3.21) \\
-\mathbf{0 . 0 0 7}\end{array}$ & $\begin{array}{c}-0.243 \\
(-2.58) \\
-0.007\end{array}$ & $\begin{array}{c}-0.273 \\
(-3.59) \\
-\mathbf{0 . 0 0 8}\end{array}$ & $\begin{array}{c}-0.257 \\
(-2.71) \\
-\mathbf{0 . 0 0 7}\end{array}$ \\
\hline
\end{tabular}


Table 4 (continued)

Australia

$-3.990$

$-1.103$

$(-2.53)$

$-0.041$

$(-0.76)$

$-3.169$

$-0.018$

Belgium

$(-2.82)$

$-3.100$

$-0.030$

$(-3.53)$

$-1.080$

$\mathbf{- 0 . 0 2 9}$

Canada

$(-1.20)$

$-0.140$

$-0.018$

$(-0.44)$

$-0.004$

Finland

$-1.417$

2.107

$(-1.22)$

(1.16)

$-0.018$

0.382

Netherlands

$-1.653$

(-1.76)

$-1.389$

$-0.021$

$(-1.83)$

$-3.924$

$-0.020$

Spain

(-2.16)

$-2.123$

$-0.038$

$(-0.99)$

$-0.024$

United Kingdom

$-4.640$

$-0.484$

$(-1.40)$

$(-0.36)$

$-0.131$

$-0.013$

Chi-squared on country dummies

70.081

89.504

[0.000]

[0.000]

$\mathrm{N}$

27,251

18,322

27,251

18,322

Note: T-statistics in parenthesis, marginal effects in bold italics, p-values in brackets for chi-squared test, and intercept not shown. 